\title{
MONITORING SATURASI OKSIGEN MENGGUNAKAN SPO2 MAX 30100 BERBASIS ANDROID
}

\author{
Oxygen Saturation Monitoring Using Android-Based Spo2 Max 30100 \\ Agoes Santika Hyperastuty $^{1}$, Yanuar Mukhammad ${ }^{2}$ \\ ${ }^{1,2}$ Prodi D-III Teknik Elektromedis Universitas Kadiri \\ Alamat Korespondensi : Prodi D-III Teknik Elektromedis \\ Jl. Selomangkleng No.1 Kota Kediri, Jawa Timur, Indonesia \\ E-mail : santika@unik-kediri.ac.id
}

\begin{abstract}
ABSTRAK
Pandemi COVID 19 melanda 188 negara dunia menyebabkan krisis global di tahun 2020. Salah satu fenomena yang terjadi adalah munculnya gejala happy hypoxia yang diduga membuat sejumlah pasien COVID-19 di Indonesia meninggal tanpa menunjukkan tanda-tanda sama sekali. Pulse oximetry merupakan suatu metode non-invasive untuk memonitor persentase saturasi oksigen dalam darah sehingga dapat mendeteksi dini kondisi hipoksia sebelum terjadi keadaan fatal dan dapat dengan segera mendapat pertolongan.

Penelitian ini menggunakan sensor Max 30100 sebagai pengambilan data. Peneliti melakukan pengambilan data sebanyak 5 kali pada 5 responden. Sensor Max30100 melakukan penyadapan Spo2 kemudian data tersebut diproses menggunakan WeMos D1 Mini serta ESP8266 yang nantinya akan ditampilkan pada LCD serta terdapat aplikasi blynk untuk mengirimkan data menuju android.

Hasil penelitian didapatkan nilai yang bervariasi pada responden dikarenakan fluktuasi pembacaan sensor terus berjalan sehingga terjadi naik turun nilai namun tidak terlalu signfikan. Tingkat keakuratan alat bisa dilihat dari nilai yang hasilkan dan juga nilai yang terbaca antara kadar oksigen pada responden ke 1 hingga ke 5 .

Sensor dapat mendeteksi dengan baik kadar oksigen dalam darah dan sensor max30100 dapat mendeteksi kadar oksigen dalam darah dengan tingkat keakuratan yang baik sehingga hasil pengukuran pada responden 1 hingga 5 setiap orangnya tidak terlalu jauh.
\end{abstract}

Kata kunci-Happy Hypoxia, Pulse Oximetry, SpO2

\section{ABSTRACT}

The COVID 19 pandemic has hit 188 countries worldwide causing a global crisis in 2020. One of the phenomena that occurs is the appearance of happy hypoxia symptoms which are thought to have caused a number of COVID-19 patients in Indonesia die without showing any signs at all. Pulse oximetry is a non-invasive method for monitoring the percentage of oxygen saturation in the blood so that it can early detect hypoxic conditions before fatal conditions occur and can immediately get help

This study uses the Max30100 sensor as a data retrieval. The researcher collect data 5 times on 5 respondents. Sensor Max30100 perform SpO2 tapping then the data is processed using WeMos D1 Mini and ESP8266 which will later be displayed on the LCD and there is a blynk application to send data to android.

The result showed that the value varies in the respondents due to the fluctuation in sensor reading, so that the value fluctuates but it is not too significant. The level of accuracy of the tool can be seen from the value generated and also the value read between the oxygen level of the $1^{\text {st }}$ to $5^{\text {th }}$ respondents.

The sensor can detect the oxygen level in the blood properly and the max30100 sensor can detect the oxygen level in the blood with a good level of accuracy so that the measurement result from respondent 1 to 5 are not too far.

Keywords- Happy Hypoxia, Pulse Oximetry, SpO2 


\section{PENDAHULUAN}

Pandemi coronavirus disease 2019 (COVID 19) melanda 188 negara dunia menyebabkan terjadinya krisis global di tahun 2020 dan di Indonesia upaya untuk mengatasi krisis terus berlangsung sampai dengan saat ini. COVID-19 merupakan penyakit baru yang masih terus diteliti. Berbagai fakta baru mengenai virus tersebut mulai terungkap salah satunya adalah munculnya gejala happy hypoxia yang diduga membuat sejumlah pasien COVID-19 di Indonesia meninggal tanpa menunjukkan tanda-tanda sama sekali.

COVID-19 pada dasarnya adalah penyakit pernapasan, dan pada kasus yang parah, penyakit tersebut dapat mengurangi jumlah oksigen yang dapat diserap paru-paru. Itulah mengapa tingkat oksigen darah yang sangat rendah ditemukan pada sejumlah pasien COVID-19 di Indonesia.

Beberapa pasien COVID-19 tidak mempunyai gejala pernapasan atau mendapati fenomena happy hypoxia yaitu suatu kondisi dimana tubuh dengan kadar oksigen darah yang sangat rendah, akan tetapi tidak ada gejala dispnea dan pasien masih bisa melakukan aktivitas normal, seperti mengobrol dan berjalan. Padahal secara teori pasien dengan kadar oksigen rendah dalam darah seharusnya tidak sadar bahkan dapat mengalami gagal organ. Akan tetapi, dilaporkan kasus pasien positif Covid-19 datang dengan presentasi klinis tidak ada gejala gangguan pernapasan ataupun kesulitan bernapas.
Sebuah studi yang dilakukan oleh Dr. Martin J. Tobin, seorang profesor kedokteran paru dan perawatan kritis di Loyola University Medical Center, di Maywood, IL, pada 16 pasien COVID-19 dengan tingkat oksigen yang rendah (memiliki nilai 50 persen dari kisaran normal 95-100 persen) yang tidak mengalami sesak napas atau dispnea ditemukan beberapa mekanisme patofisiologis bertanggung jawab atas sebagian besar kasus silent hypoxia, termasuk penilaian awal tingkat oksigen pasien dengan pulse oksimetri. Pulse oksimetri sangat akurat saat pembacaan oksigen tinggi, namun alat tersebut dapat melebih-lebihkan tingkat keparahan kadar oksigen yang rendah pada seseorang saat pembacaan rendah. Bagaimana respon otak terhadap tingkat oksigen yang rendah juga adalah salah satu faktor yang menyebabkan pengidap COVID-19 tidak merasakan gejala apa-apa saat mengalami hypoxia. Ketika kadar oksigen pengidap menurun, otak tidak merespons sampai oksigen turun ke tingkat yang sangat rendah. Selain itu, lebih dari separuh pengidap COVID-19 juga memiliki kadar karbon dioksida yang rendah yang dapat mengurangi dampak kadar oksigen yang sangat rendah. Dr. Tobin juga mencurigai bahwa virus corona dapat memengaruhi reseptor tubuh sehingga tidak merespons pada tingkat oksigen yang rendah. Hal ini dikaitkan dengan kurangnya penciuman yang ditemukan pada dua pertiga pasien COVID-19.

Pulse oximetry merupakan suatu metode non-invasive yang digunakan di luar organ tubuh untuk memonitor persentase saturasi 
oksigen dalam darah. sehingga dapat mendeteksi dini kondisi hipoksia sebelum terjadi keadaan fatal dan dapat dengan segera mendapat pertolongan. Seiring dengan perkembangan waktu, oximeter terus dikembangkan bahkan kini beberapa smartphone telah disematkan sensor oximeter yang dapat mendeteksi saturasi oksigen dalam darah (Naufal F, dkk).

Smartphone yang dimiliki hampir semua orang lebih portable, bisa diakses di mana pun dan kapan pun sehingga Pulse oximeter berbasis smartphone diharapkan dapat meningkatkan deteksi dini happy hypoxia dan dapat mengurangi angka pasien perawatan intensif (ICU), perawatan invasif (ventilator dan intubasi), dan mortalitas pasien karena COVID-19.

\section{Rumusan Masalah}

Adapun rumusan masalah yang akan dibahas pada penelitian ini meliputi :

1. Bagaimana merancang dan membangun pulse oximetry dengan dua parameter pengukuran yaitu $\mathrm{SpO} 2$ dan pulse rate.

2. Bagaimana cara kerja sistem alarm prioritas sebagai penanda terjadinya kegagalan pada pulse oximetry.

\section{Batasan Masalah}

Sesuai rumusan masalah yang telah dikemukakan, maka adapun batasan masalah yang dapat dikaitkan dalam penelitian ini yaitu

a. Rancang bangun pulse oximetry dengan $\mathrm{SpO} 2$ dan pulse rate sebagai parameter utama untuk memantau keadaan pasien dengan menggunakan ATmega 8535. b. Pelaksanaan sistem alarm prioritas untuk menunjukkan prioritas kegagalan yang harus segera ditangani dan sebagai vital monitoring terhadap kondisi pasien.

\section{Tujuan Penelitian}

Adapun tujuan dari penelitian yang dilakukan yaitu:

a. Merancang dan membangun pulse oximetry dengan dua parameter utama yaitu $\mathrm{SpO} 2$ dan pulse rate.

b. Membangun aplikasi penampilan dua parameter tersebut sebagai vital monitoring terhadap pasien.

c. Membangun sistem alarm prioritas pada pulse oximetry sebagai penanda terjadinya kondisi yang tidak normal pada pasien maupun alat

\section{BAHAN DAN METODE}

A. Rancangan penelitian

Penelitian ini menggunakan sensor Max 30100 sebagai pengambilan data. Peneliti melakukan pengambilan data sebanyak 5 kali pada 5 responden

1. Alat dan Bahan

Penelitian ini menggunakan sensor Max 30100 sebagai penyadap Spo2. Tampilan pada alat ini menggunakan LCD 16x2 serta aplikasi Blynk sebagai aplikasi untuk android

2. Percobaan

Dalam studi ini, setelah desain jadi, dilakukan pengujian hasil dari pembacaan sensor Max 30100. Hasil dari pembacaan dapat di monitoring 
ditampilkan di LCD dan Blnyk vital monitoring terhadap kondisi pasien.

\section{B. Blok diagram}

Dalam penelitian ini, sensor Max30100 melakukan penyadapan Spo2. Kemudian data tersebut diproses menggunakan WeMos D1 Mini serta ESP8266 yang nantinya akan ditampilkan pada LCD serta terdapat aplikasi blynk untuk mengirimkan data menuju android .

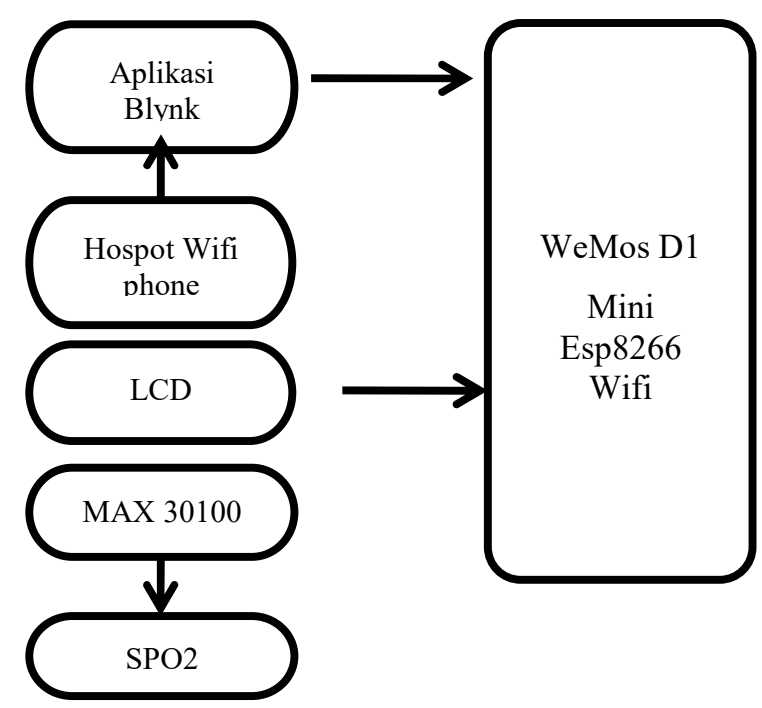

Gambar.1. Blok diagram

1. $\operatorname{Max} 30100$

Max 30100 berfungsi sebagai penyadap Spo2.

2. LCD

LCD sebagai tampilan yang akan menampilkan hasil sadapan sensor $\operatorname{Max} 30100$.

3. WeMos D1 mini Wifi

WeMos D1 mini Wifi sebagai pengolah data .
4. Aplikasi Blynk

Aplikasi Blynk adalah Aplikasi untuk iOS dan OS Android untuk mengontrol WeMos D1, dapat di gunakan untuk mengendalikan perangkat hadware, menampilkan data sensor dan lain-lain.

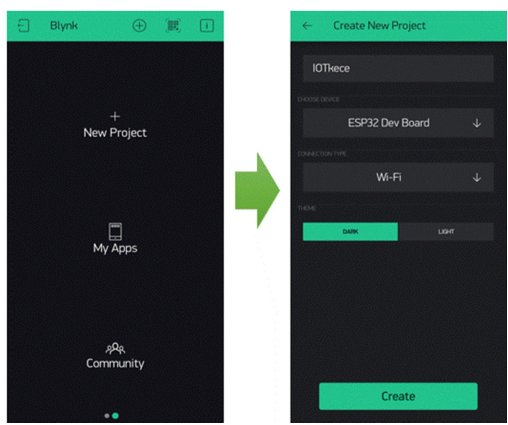

Gambar 2. Aplikasi Blynk

C. Diagram Alur

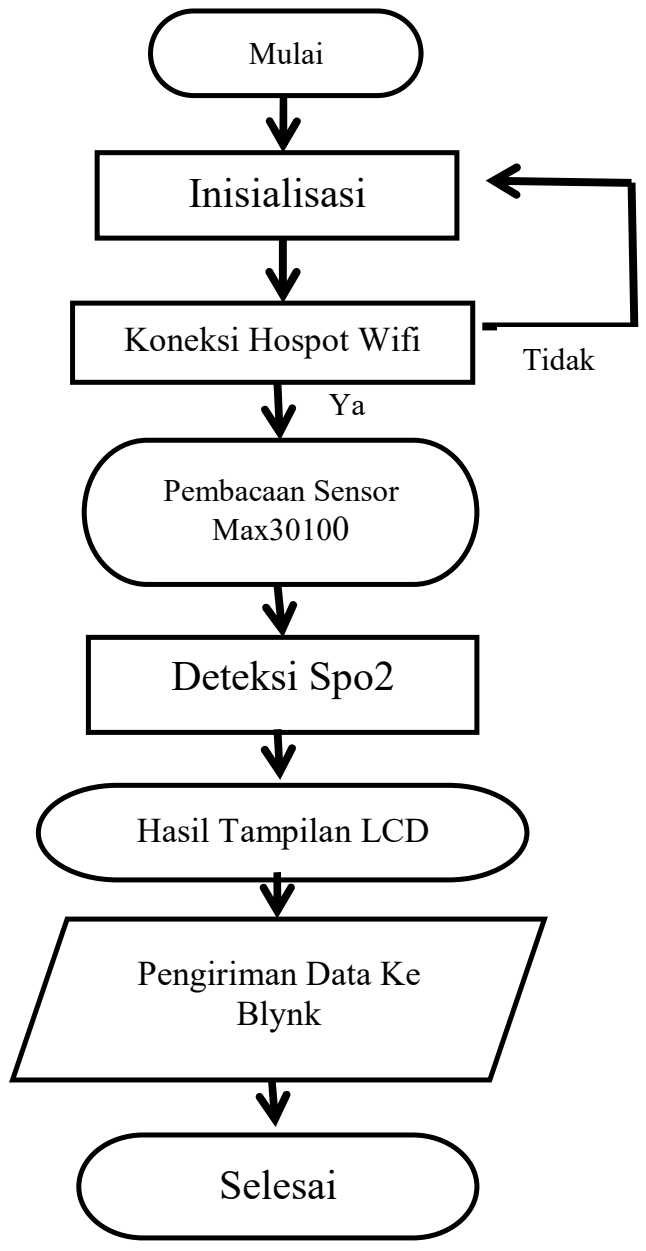

Gambar.3. Diagram alur transmitter 


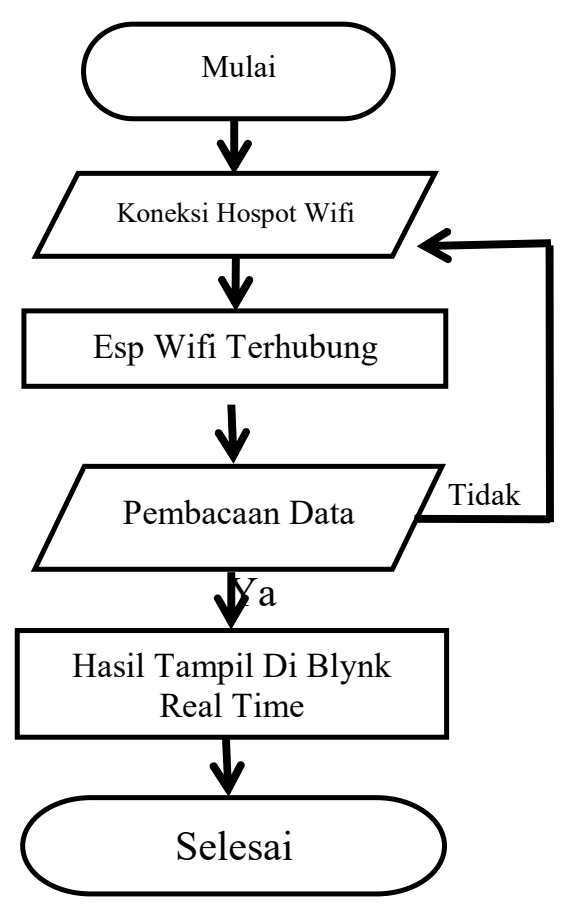

Gambar.4. Diagram alur recevier

Pada saat alat mulai start maka LCD akan menginisialisasi pada saat itu juga sensor Max30100 akan memulai penyadapan sudah berjalan. Kemudian hasil akan ditampilkan pada layar LCD dan hasil data akan dikirimkan melalui Aplikasi blynk ditunjukan pada gambar.2

Pada saat Aplikasi Blynk sudah terkoneksi internet kemudian data akan dikirimkan melalui hospot wifi yang sudah terhubung dan akan ditampilkan di Aplikasi Blynk yang sudah dibuat penampilan datanya.
D. Skema rangkaian

Perancangan perangkat keras untuk alat montoring Spo2 terdiri dari beberapa komponen dasar yaitu sensor Max30100, Mikrokontroller WeMos D1 mini dan LCD 16x2. Sensor yang digunakan adalah Max30100 karena tingkat akurasi yang baik dikarenakan sensor ini adalah sensor digital sehingga mudah untuk di kalibrasi.

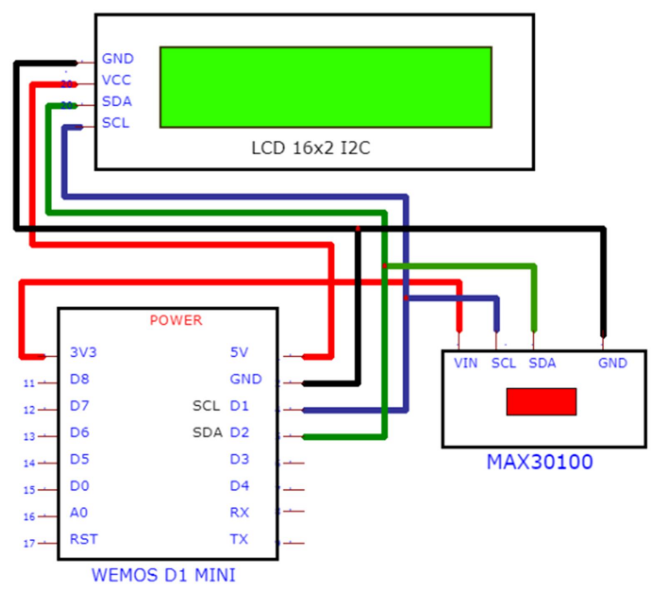

Gambar.5. Skema rangkaian alat

\section{HASIL DAN PEMBAHASAN}

Hasil yang didapat dari pengujian 5 kali percobaan didapat hasilnya cukup akurat yaitu seperti pada tabel 1 berikut

\begin{tabular}{lcccccc} 
Pasien & & Kadar1 & Kadar2 & Kadar3 & Kadar4 & Kadar5 \\
\hline Orang & ke & 96 & 92 & 86 & 95 & 98 \\
1 & & & & & & \\
\hline Orang & ke & 89 & 96 & 95 & 97 & 93 \\
2 & & & & & & \\
\hline Orang & ke & 97 & 94 & 91 & 88 & 96 \\
3 & & & & & & \\
\hline Orang & ke & 97 & 98 & 96 & 94 & 98 \\
4 & & & & & & \\
\hline Orang ke & 94 & 98 & 95 & 97 & 98 \\
5 & & & & &
\end{tabular}


Pada Tabel 1 terlihat nilai yang bervariasi tiap orangnya dikarenakan fluktuasi pembacaan sensor terus berjalan sehingga terjad naik turun nilai namun tidak terlalu signfikan. Jadi dilakukan 5 kali percobaan pada setiap orang dengan alat yang sama lalu nilai yang dihasilkan di catat. Tingkat keakuratan alat bisa dilhat dari nilai yang hasilkan dan juga nilai yang terbaca antara kadar1 hingga ke 5. Pada percobaan disimpulkan bahwa sensor dapat mendeteksi dengan baik kadar oksigen dalam darah dengan akuratan sensor max30100 yang bisa dipakai ini dibuktikan dengan perbedaan kadar 1 hingga 5 tiap2 orang tidak terlalu jauh bedanya.

\section{PENUTUP}

Bahwa sensor $\max 30100$ dapat mendeteksi kadar oksigen dalam darah dengan keakuratan yang baik sehingga hasil sample 1 hingga 5 setiap orangnya tidak terlalu jauh.

\section{UCAPAN TERIMA KASIH}

Terimakasih kepada Laboratorium Elektromedik Universitas Kadiri yang telah memberikan tempat untuk perngerjaan alat dan juga penyusunan artikel.

\section{DAFTAR PUSTAKA}

Naufal, F., Rifa'I, A. (2020). Smartphone Pulse Oximeter : Solusi Deteksi Dini Happy Hypoxia. JIMKI volume 8 no 3.

Eryanda Bima Mahendra, Bambang Guruh, Irianto, EndroYulianto, (2019). Perancangan Smartwatch Spo2 dan BPM Dengan Tampilan Android,

M. Erliyanto and S. S. Ir, (2008). "Perancangan Perangkat Monitoring Denyut Jantung (Heart-Beat Monitoring) Dengan Visualisasi Lcd Grafik Berbasis Atmel At89C51," Konf. Nas. Sist. dan Inform., pp. 294-299.

R. H. Simanjuntak, J. N. A. Engka, and S. R. Marunduh. (2016). "Pengaruh Latihan Fisik Akut Terhadap Saturasi Oksigen Pada Pemain Basket Mahasiswa Fakultas Kedokteran Unsrat," J. e-Biomedik, vol. 4, no. 1, pp. 2024.

M. W. E. Tirajoh, J. F. Rumampuk, and F. LIntong. (2016). "Pengaruh Minuman Berkadar Oksigen Tinggi Terhadap Saturasi Oksigen Pada Olahraga Lari," J. Kedokt. Klin., vol. 1 , no. 1 , pp. $76-82$. 